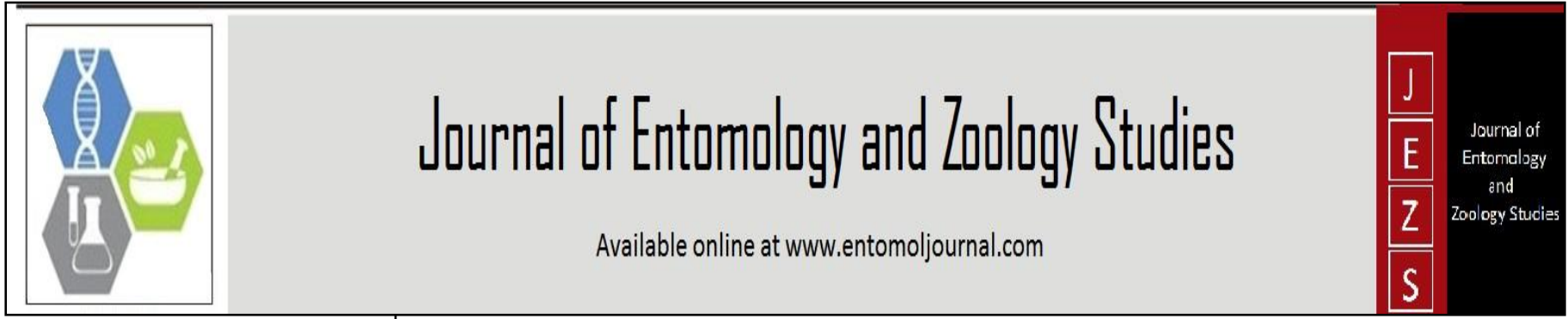

E-ISSN: 2320-7078 P-ISSN: 2349-6800 JEZS 2018; 6(4): 126-129

(C) 2018 JEZS

Received: 11-05-2018

Accepted: 12-06-2018

MA Laichattiwar

School of APES, University of the Witwatersrand, R.S.A South Africa

\section{A review of studies on the fire millipede genus centrobolus (diplopoda: trigoniulidae)}

\section{Mark Cooper}

\section{Abstract}

Studies on Centrobolus spp. were reviewed in which mechanisms of selection, sperm competition and cryptic female choice were studied. Approaches (1) quantify size dimorphism and find the selection pressures operating on the sexes, (2) determine the functional significance of male and female genitalia, (3) understand why there should be a conflict of sexual interests in prolonged copulations, and (4) resolve the mechanisms of sperm competition and cryptic female choice in comparing male mating strategies to female sperm usage were included.

Keywords: choice, competition, conflict, copulation, cryptic

\section{Introduction}

Originally, sexual selection was conceived as operating in two distinct processes of male-male competition and female choice ${ }^{[1]}$. The distinction between the two processes became modified into male-male competition and epigamic selection because all selections were considered between sexes ${ }^{[2]}$. Further major theoretical changes took place, one of which was to show how the strength of selection could be measured as offspring production relative to mating success [3]. Sperm competition was the manifestation of male-male competition whereby rival males competed for fertilizations rather than mating per se ${ }^{[4]}$. Cryptic female choice involved selection for courtship, elaborate male genitalia, and post-copulation products $[5,6]$. The dynamics within a mating system may be an evolutionary stable balance between the two mechanisms or the outcome of a conflict of interests between the sexes ${ }^{[7]}$. Different forms of sperm storage, and the sperm storage organs themselves, determine the use of the remaining rivals' sperm in fertilization ${ }^{[6]} .34$ studies on the Centrobolus genus were reviewed in which mechanisms of selection; sperm competition and cryptic female choice were studied. Approaches to: (1) quantify size dimorphism and find the selection pressures operating on the sexes, (2) determine the functional significance of male and female genitalia, (3) understand why there should be a conflict of sexual interests in prolonged copulations, and (4) resolve the mechanisms of sperm competition and cryptic female choice in comparing male mating strategies and sperm precedence to female mating strategies and sperm usage were included. The conclusions from 25 studies were moderated and tabulated here.

\section{Materials and Methods}

35 studies of the behavioural ecology of millipedes in southern Africa were reviewed and referenced. Short digital object identifier's were constructed for each publication at the site http://shortdoi.org/. The conclusions of the publications were tabulated (Table 1).

\section{Results}

35 studies of the behavioural ecology of millipedes in southern Africa were shown ${ }^{[8-43]}$. 
Table 1. Conclusions from the 25 of 35 studies in the genus Centrobolus Cook.

\begin{tabular}{|c|c|}
\hline Conclusion & Reference \\
\hline $\begin{array}{l}\text { Mate avoidance and mating hotspots are not mutually exclusive hypotheses and both need testing. Additional } \\
\text { knowledge on millipede reproductive systems can be useful in forest regeneration plans. }\end{array}$ & Cooper $2014 a$ \\
\hline $\begin{array}{l}\text { Evidence exists for all of the predictions of mate-guarding except for showing (1) mate guarding is energetically } \\
\text { costly, and (2) as the time between copulation and ovule position protracts it becomes less likely for males to } \\
\text { remain with their partners. }\end{array}$ & $\begin{array}{c}\text { Cooper } 2016 \\
\text { http://doi.org/cn6v }\end{array}$ \\
\hline Four species of Centrobolus were confirmed in gonopod ultrastructure. & $\begin{array}{l}\text { Cooper } 2016 a, b \\
\text { http://doi.org/cn6w, } \\
\text { http://doi.org/cn6x }\end{array}$ \\
\hline $\begin{array}{l}\text { There was no evidence for male control of copulation duration in Centrobolus. Evidence from the literature } \\
\text { suggests female control of copulation duration in C. inscriptus. }\end{array}$ & $\begin{array}{c}\text { Cooper } 2016 c \\
\text { http://doi.org/cn62 }\end{array}$ \\
\hline The reduced copulation durations in hetero-specific crosses may be explained as the female sooner norm $\left(\hat{a}^{0}\right)$. & $\begin{array}{c}\text { Cooper } 2016 d \\
\text { http://doi.org/cn63 }\end{array}$ \\
\hline Centrobolus gonopods possess structures with functions in sperm displacement. & $\begin{array}{c}\text { Cooper } 2016 e \\
\text { http://doi.org/cn64 }\end{array}$ \\
\hline $\begin{array}{l}\text { The sexual differences between male and female body plans which is observable in millipedes may be } \\
\text { biologically significant. The variance in the female form, together with the distributions of the measurements } \\
\text { taken for } C \text {. inscriptus, illustrated most dimorphism was continuous and there is directional selection for } \\
\text { heavier-shorter-wider females. }\end{array}$ & $\begin{array}{c}\text { Cooper } 2016 f \\
\text { http://doi.org/cn65 }\end{array}$ \\
\hline $\begin{array}{l}\text { Instantaneous insemination was demonstrated using artificially terminated mating in } C \text {. inscriptus in showing no } \\
\text { relationship between ejaculate volume and copulation duration except for high and low volumes at the beginning } \\
\text { of mating when the male loads and seats the gonopods before adaptive mate-guarding as prolonged copulation. }\end{array}$ & $\begin{array}{c}\text { Cooper } 2016 g \\
\text { http://doi.org/cn66 }\end{array}$ \\
\hline $\begin{array}{c}\text { Differences in the number of male and female stadia in } C \text {. inscriptus provide preliminary evidence for sexual } \\
\text { bimaturism in arthropods. }\end{array}$ & $\begin{array}{c}\text { Cooper } 2016 h \\
\text { http://doi.org/cn67 }\end{array}$ \\
\hline $\begin{array}{l}\text { Larger females prolong copulation duration according to their body size in } C \text {. inscriptus but a conflict over } \\
\text { terminating copulations was suggested due to the correlation between SSD and copula duration. }\end{array}$ & $\begin{array}{c}\text { Cooper } 2016 i \\
\text { http://doi.org/cn68 }\end{array}$ \\
\hline $\begin{array}{l}\text { During the } 24 \mathrm{~h} \text { post-mating ejaculate volumes in C. inscriptus consistently decline and this was due to sperm } \\
\text { dumping. }\end{array}$ & $\begin{array}{c}\text { Cooper } 2016 j \\
\text { http://doi.org/cn69 }\end{array}$ \\
\hline $\begin{array}{l}\text { Symmetry in ejaculate volumes was consistent with the mechanism of sperm displacement } i . e \text {. mixing-self- } \\
\text { sperm displacement. }\end{array}$ & $\begin{array}{l}\text { Cooper } 2016 m, n \\
\text { http://doi.org/cn7d, } \\
\text { http://doi.org/cn7f }\end{array}$ \\
\hline Mate-guarding was affected by predation in the millipede $C$. inscriptus. & $\begin{array}{c}\text { Cooper } 2016 o \\
\text { http://doi.org/cn7g }\end{array}$ \\
\hline $\begin{array}{l}\text { Elaborate tarsal pads of the Centrobolus males appear not to be an adaptation for supporting the body column } \\
\text { but sexually selected. }\end{array}$ & $\begin{array}{c}\text { Cooper } 2016 p \\
\text { http://doi.org/cn } 7 \mathrm{~h}\end{array}$ \\
\hline $\begin{array}{l}\text { Copulations of second males were significantly related to male body mass in the presence of sexual size } \\
\text { dimorphism in double mating experiments of } C \text {. inscriptus. }\end{array}$ & $\begin{array}{c}\text { Cooper } 2016 q \\
\text { http://doi.org/cn7j }\end{array}$ \\
\hline $\begin{array}{l}\text { C. inscriptus was a large member of the genus with relatively large males and smaller females compared to } 18 \\
\text { Centrobolus species for which data is available. }\end{array}$ & $\begin{array}{c}\text { Cooper } 2016 r \\
\text { http://doi.org/cn7k }\end{array}$ \\
\hline $\begin{array}{l}\text { The inverse of Rensch's rule was found in Centrobolus based on the positive relationship between SSD and } \\
\text { body size. }\end{array}$ & $\begin{array}{c}\text { Cooper } 2017 \\
\text { http://doi.org/cn7n }\end{array}$ \\
\hline Body mass in southern African worm-like millipedes positively relates to copulation duration. & $\begin{array}{c}\text { Cooper } 2017 a \\
\text { http://doi.org/cn } 7 \mathrm{~m}\end{array}$ \\
\hline $\begin{array}{c}\text { Sexual size dimorphism in southern African worm-like millipedes inversely relates to copulation duration } \\
\text { because larger males copulate for shorter and larger females copulate for longer. }\end{array}$ & $\begin{array}{c}\text { Cooper } 2017 b \\
\text { http://doi.org/cn } 7 \mathrm{p}\end{array}$ \\
\hline $\begin{array}{l}\text { C. digrammus was unlike } C \text {. inscriptus with ordinarily small males and larger females which are similar } \\
\text { compared to } 18 \text { Centrobolus species for which data is available. }\end{array}$ & $\begin{array}{c}\text { Cooper } 2017 c \\
\text { http://doi.org/cn7r }\end{array}$ \\
\hline $\begin{array}{l}\text { C. fulgidus was similar to C. inscriptus with small males and larger females compared to } 18 \text { Centrobolus species } \\
\text { for which data is available. }\end{array}$ & $\begin{array}{c}\text { Cooper } 2017 d \\
\text { http://doi.org/cn7s }\end{array}$ \\
\hline C. ruber males and females followed the trend for SSD and (break) Rensch's rule in Centrobolus. & $\begin{array}{c}\text { Cooper } 2017 e \\
\text { http://doi.org/cn7t }\end{array}$ \\
\hline $\begin{array}{l}\text { Copulation duration related to male length in double mating } C \text {. inscriptus. Second mating intra-pair SSD is } \\
\text { under female control and affects ejaculate precedence. }\end{array}$ & $\begin{array}{c}\text { Cooper } 2017 f \\
\text { http://doi.org/cn7q }\end{array}$ \\
\hline $\begin{array}{l}\text { Copulations of females were significantly related to female body width in the presence of sexual size } \\
\text { dimorphism in double mating experiments of } C \text {. inscriptus. }\end{array}$ & $\begin{array}{c}\text { Cooper } 2017 g \\
\text { http://doi.org/cn7v }\end{array}$ \\
\hline $\begin{array}{l}\text { Diplopoda SSD does not negatively regress with body sizes but break Rensch's rule. Intersexual competition } \\
\text { was believed to drive SSD in diplopods with forest taxa containing the diversity of species and sizes. A } \\
\text { geometric morphometric approach successfully determined the shape and size of millipedes which enabled us to } \\
\text { see a relationship, or lack hereof, between shape as size and SSD. The inverse of Rensch's rule was found in } \\
\text { Centrobolus based on the relationship between SSD and body size. }\end{array}$ & $\begin{array}{l}\text { Cooper } 2018 a, b, c \\
\text { http://doi.org/cn7x, } \\
\text { http://doi.org/cn7z, } \\
\text { http://doi.org/cn72 }\end{array}$ \\
\hline
\end{tabular}

\section{Discussion}

35 publications included data from Centrobolus. Mate avoidance and mating hotspots are not mutually exclusive hypotheses and both needed testing ${ }^{[7]}$. Evidence exists for all of the predictions of mate-guarding except for showing (1) mate guarding is energetically costly in Centrobolus, and (2) as the time between copulation and ovule position protracts it becomes less likely for males to remain with their partners ${ }^{[11]}$.
The first prediction was confirmed and inferred from evidence in the millipede Alloporus (=Doratogonus) uncinatus which shows copulations are energetically costly ${ }^{[12]}$. Four species of Centrobolus were confirmed by gonopod ultrastructure ${ }^{[13-14]}$, leaving the second prediction to be tested. There was no evidence for male control of copulation duration in Centrobolus; evidence from the literature suggests female control of copulation duration in $C$. inscriptus ${ }^{[15]}$. The 
reduced copulation durations in hetero-specific crosses may be explained by the female sooner norm $\left(\hat{a}^{o}\right)^{[16]}$. Centrobolus gonopods possess structures with functions in sperm displacement ${ }^{[17]}$. The sexual differences between male and female body plans which was observable in millipedes may be biologically significant ${ }^{[18]}$. The variance in the female form, together with the distributions of the measurements taken for $C$. inscriptus, illustrated most dimorphism was continuous and there was directional selection for heaviershorter-wider females ${ }^{[18]}$. Instantaneous insemination was demonstrated using artificially terminated mating in $C$. inscriptus in showing no relationship between ejaculate volume and copulation duration except for high and low volumes at the beginning of mating when the male loads and seats the gonopods before adaptive mate-guarding by prolonged copulation ${ }^{[19]}$. Differences in the number of male and female stadia in $C$. inscriptus provided preliminary evidence for sexual bimaturism in arthropods ${ }^{[20]}$. Larger females prolonged copulation duration according to their body size in $C$. inscriptus but a conflict over terminating copulations was suggested due to the correlation between SSD and copulation duration in double mating ${ }^{[21]}$. During the $24 \mathrm{~h}$ post-mating, ejaculate volumes in $C$. inscriptus consistently declined and this was due to sperm dumping ${ }^{[22]}$. Symmetry in ejaculate volumes was consistent with the mechanism of sperm displacement $i$. e. mixing-self-sperm displacement ${ }^{[25-26]}$. Mate-guarding was affected with predation in the millipede $C$. inscriptus ${ }^{[27]}$. Elaborate tarsal pads of the Centrobolus males appeared not to be an adaptation for supporting the body column but sexually selected ${ }^{[28]}$. Copulations of second males were significantly related to male body mass in the presence of sexual size dimorphism in double mating experiments of $C$. inscriptus ${ }^{[29]}$. Copulations of second males were significantly related to male body mass in the presence of sexual size dimorphism in double mating experiments of $C$. inscriptus; a large member of the genus with relatively large males and smaller females compared to 18 Centrobolus species for which data was available [30]. The inverse of Rensch's rule was found in Centrobolus based on the positive relationship between SSD and body size ${ }^{[31]}$. Body mass in southern African worm-like millipedes positively related to copulation duration ${ }^{[32]}$. Sexual size dimorphism in southern African worm-like millipedes inversely related to copulation duration because larger males copulate for shorter and larger females copulate for longer ${ }^{[33]}$. C. digrammus was unlike $C$. inscriptus with ordinarily small males and larger females which are similar compared to 18 Centrobolus species for which data was available ${ }^{[34]}$. $C$. fulgidus was similar to $C$. inscriptus with small males and larger females compared to 18 Centrobolus species for which data was available ${ }^{[35]}$. C. ruber males and females followed the trend for SSD and (break) Rensch's rule in Centrobolus [36]. Copulation duration related to male length in double mating $C$. inscriptus and second mating intra-pair SSD was under female control and affected ejaculate precedence ${ }^{[37]}$. Copulations of females were significantly related to the female body width in the presence of sexual size dimorphism in double mating experiments of $C$. inscriptus ${ }^{[38]}$. Diplopoda SSD does not negatively regress with body sizes but break Rensch's rule ${ }^{[39]}$. Intersexual competition was believed to drive SSD in diplopods with forest taxa containing the diversity of species and sizes ${ }^{[40-41]}$. Sexual size dimorphism and the rejection of Rensch's rule in Diplopoda (Arthropoda) was based on Trigoniulids, Sphaerotheriids and Spirostreptids [41-43].

\section{Conclusion}

In millipedes there were trends of instantaneous insemination and sperm displacement in males during the adaptive mate guarding phase. Dynamic behaviours which evolved through male-male competition and choice were observed.

\section{References}

1. Darwin CR. The descent of man and selection in relation to sex. John Murray, London, 1871.

2. Huxley J. Darwin's theory of sexual selection. American Naturalist. 1938; 72:416-433.

3. Bateman AJ. Intra-sexual selection in Drosophila. Heredity. 1948; 2:349-368.

4. Parker GA. Sperm competition and its evolutionary consequences in the insects. Biological Reviews. 1970; 45:525-567.

5. Thornhill RT. Cryptic female choice and its implications in the scorpionfly Harpobittacus nigriceps. American Naturalist. 1983; 28:52-59.

6. Eberhard WG. Female Control. Princeton University Press, Princeton, 1996.

7. Smith RL. Sperm Competition and the Evolution of Animal Mating Systems. Academic Press, New York, 1984.

8. Cooper MI. Sex ratios, mating frequencies and relative abundance of sympatric millipedes in the genus Chersastus. Arthropods. 2014; 3(4):174-176.

9. Cooper MI. Sexual size dimorphism and corroboration of Rensch's rule in Chersastus millipedes. Journal of Entomology and Zoology Studies. 2014; 2(6):264-266.

10. Cooper MI. Competition affected by re-mating interval in a myriapod. Journal of Entomology and Zoology Studies. 2015; 3(4):77-78.

11. Cooper MI. Elaborate gonopods in the myriapod genus Chersastus. Journal of Entomology and Zoology Studies. 2015; 3(4):235-238.

12. Telford SR, Webb PI. The energetic cost of copulation in a polygynandrous millipede. The Journal of Experimental Biology. 1998; 201(11):1847-1849.

13. Cooper M. Post-insemination associations between males and females in Diplopoda. Journal of Entomology and Zoology Studies. 2016; 4(2):283-285.

14. Cooper MI. Confirmation of four species of Centrobolus Cook based on gonopod ultrastructure. International Journal of Entomology Research. 2016; 1(3):7-9.

15. Cooper MI. Confirmation of four species of Centrobolus Cook based on gonopod ultrastructure. Journal of Entomology and Zoology Studies. 2016; 4(4):389-391.

16. Cooper MI. Do females control the duration of copulation in the aposematic millipede Centrobolus inscriptus? Journal of Entomology and Zoology Studies. 2016; 4(6):623-625.

17. Cooper MI. Fire millipedes obey the female sooner norm in cross mating Centrobolus Cook. Journal of Entomology and Zoology Studies. 2016; 4(1):173-174.

18. Cooper MI. Gonopod mechanics in Centrobolus Cook. Journal of Entomology and Zoology Studies. 2016; 4(2):152-154.

19. Cooper MI. Heavier-shorter-wider females in the millipede Centrobolus inscriptus (Attems). Journal of Entomology and Zoology Studies. 2016; 4(2):509-510.

20. Cooper MI. Instantaneous insemination in the millipede Centrobolus inscriptus (Attems) determined by artificially terminated mating. Journal of Entomology and Zoology Studies. 2016; 4(1):487-490. 
21. Cooper MI. Sexual bimaturism in the millipede Centrobolus inscriptus (Attems). Journal of Entomology and Zoology Studies. 2016; 4(3):86-87.

22. Cooper MI. Sexual conflict over the duration of copulation in Centrobolus inscriptus (Attems). Journal of Entomology and Zoology Studies. 2016; 4(6):852-854.

23. Cooper MI. Sperm dumping in Centrobolus inscriptus (Attems). Journal of Entomology and Zoology Studies. 2016; 4(4):394-395.

24. Cooper MI. Sperm storage in Centrobolus Cook and observational evidence for egg simulation. Journal of Entomology and Zoology Studies. 2016; 4(1):127-129.

25. Cooper MI. Sperm storage in Centrobolus inscriptus (Attems). Journal of Entomology and Zoology Studies. 2016; 4(4):392-393.

26. Cooper MI. Symmetry in ejaculate volumes of Centrobolus inscriptus (Attems). International Journal of Entomology Research. 2016; 1(2):14-15.

27. Cooper MI. Symmetry in ejaculate volumes of Centrobolus inscriptus (Attems). Journal of Entomology and Zoology Studies. 2016; 4(1):386-387.

28. Cooper MI. Syncopulatory mate-guarding affected by predation in the aposematic millipede Centrobolus inscriptus in a swamp forest. Journal of Entomology and Zoology Studies. 2016; 4(6):483-484.

29. Cooper MI. Tarsal pads of Centrobolus Cook. Journal of Entomology and Zoology Studies. 2016; 4(3):385-386.

30. Cooper MI. The influence of male body mass on copulation duration in Centrobolus inscriptus (Attems). Journal of Entomology and Zoology Studies. 2016; 4(6):804-805.

31. Cooper MI. The relative sexual size dimorphism of Centrobolus inscriptus (Attems) compared to 18 congenerics. Journal of Entomology and Zoology Studies. 2016; 4(6):504-505.

32. Cooper M. Re-assessment of rensch's rule in Centrobolus. Journal of Entomology and Zoology Studies. 2017; 5(6):2408-2410.

33. Cooper MI. Allometry of copulation in worm-like millipedes. Journal of Entomology and Zoology Studies. 2017; 5(3):1720-1722.

34. Cooper MI. Copulation and sexual size dimorphism in worm-like millipedes. Journal of Entomology and Zoology Studies. 2017; 5(3):1264-1266.

35. Cooper MI. Relative sexual size dimorphism in Centrobolus digrammus (Pocock) compared to 18 congenerics. Journal of Entomology and Zoology Studies. 2017; 5(2):1558-1560.

36. Cooper MI. Relative sexual size dimorphism in Centrobolus fulgidus (Lawrence) compared to 18 congenerics. Journal of Entomology and Zoology Studies. 2017; 5(3):77-79.

37. Cooper MI. Relative sexual size dimorphism Centrobolus ruber (Attems) compared to 18 congenerics. Journal of Entomology and Zoology Studies. 2017; 5(3):180-182.

38. Cooper MI. Size matters in myriapod copulation. Journal of Entomology and Zoology Studies. 2017; 5(2):07-208.

39. Cooper MI. The affect of female body width on copulation duration in Centrobolus inscriptus (Attems). Journal of Entomology and Zoology Studies 2017; 5(1):732-733.

40. Cooper MI. Allometry for sexual dimorphism in millipedes (Diplopoda), Journal of Entomology and Zoology Studies. 2018; 6(1):91-96.

41. Cooper MI. Sexual dimorphism in pill millipedes
(Diplopoda). Journal of Entomology and Zoology Studies. 2018; 6(1):613-616.

42. Cooper MI. Sexual size dimorphism and the rejection of Rensch's rule in Diplopoda (Arthropoda). Journal of Entomology and Zoology Studies. 2018; 6(1):1582-1587.

43. Cooper MI. Trigoniulid size dimorphism rejects Rensch. Journal of Entomology and Zoology Studies. 2018; 6(3):1232-1234.

44. Cooper MI. A review of studies on the fire millipede genus Centrobolus (Diplopoda: Trigoniulidae). Journal of Entomology and Zoology Studies, 2018. 